\title{
Considerations on the Taxonomy of the Genus Arhuaco Adams and Bernard 1977, and its Relationships with the Genus Pronophila Doubleday [1849] (Nymphalidae, Satyrinae)
}

\author{
TW Pyrcz ${ }^{1,2}$, J Lorenc-Brudecka ${ }^{1}$ (D) A Zubek ${ }^{2}$, C Prieto ${ }^{3,4}$, P Boyer ${ }^{5}$, K Florczyk ${ }^{1}$, B WactaWik ${ }^{2}$, \\ D Lachowska-CierLIK ${ }^{2}$
}

\author{
${ }^{1}$ Nature Education Centre, Jagiellonian Univ, Kraków, Poland \\ ${ }^{2}$ Entomology Dept, Institute of Zoology and Biomedical Research, Jagiellonian Univ, Kraków, Poland \\ ${ }^{3}$ Depto de Biología, Universidad del Atlántico, Barranquilla, Colombia \\ ${ }^{4}$ SNSB-Bavarian State Collection of Zoology, Munich, Germany \\ ${ }^{5} 7$ Lotissement l'Horizon, Le Puy Sainte Réparade, France
}

\section{Keywords}

Arhuaco, cloud forests, Costa Rica, Sierra Nevada de Santa Marta, Pronophila, Pronophilina, $\mathrm{COI}, \mathrm{RpS} 5$

\section{Correspondence}

J Lorenc-Brudecka, Nature Education Centre, Jagiellonian Univ, Gronostajowa 5, 30-387 Kraków, Poland; j.lorencbrudecka@uj.edu.pl

Edited by André VL Freitas - UNICAMP

Received 18 October 2017 and accepted 27 September 2018

Published online: 10 November 2018

(C) The Author(s) 2018

\begin{abstract}
Arhuaco Adams \& Bernard (1977) is one of the least known genera of Neotropical Satyrinae. It comprises two species and presents an unusual disjunct distribution, with A. ica Adams \& Bernard (1977), endemic to the isolated Colombian Sierra Nevada de Santa Marta, and A. dryadina (Schaus 1913) found in the mountains of Costa Rica and Panama. Here, the female of $A$. dryadina is described, and a new generic diagnosis is presented. Affinities with other genera of the subtribe Pronophilina, in particular the potential closest relatives, such as Pronophila Doubleday (1849), are investigated based on morphological, molecular, ecological, and behavioral data. Results from molecular and morphological sources are incongruent. Molecular data indicate that Arhuaco is paraphyletic, with A. dryadina segregating within the Pronophila clade. Morphological data, by contrast, indicate a closer affinity between the two species currently placed in Arhuaco, favoring the monophyly of the genus, and show no consistent synapomorphies for Arhuaco + Pronophila. A vicariance biogeographical scenario is evaluated.
\end{abstract}

\section{Introduction}

Research on Neotropical satyrines (Nymphalidae, Satyrinae) has intensified during the last decade, and a number of valuable contributions have been published on their relationships and taxonomy, using molecular, morphological, early-stage, and ecological data, vastly expanding our knowledge on the evolution of this group of butterflies, and in particular of the montane genera (e.g., Peña et al 2011, Pyrcz et al 2009, Casner \& Pyrcz 2010, Marín et al 2017, Pyrcz et al 2017). However, the two subtribes Pronophilina and Euptychiina, which constitute the bulk of Neotropical Satyrinae, are extremely diverse with well over 1000 species and at least 100 genera (Lamas 2004, Pyrcz 2010), and several genera have still not been thoroughly investigated.

One of these is Arhuaco Adams \& Bernard 1977, arguably one of the least studied and most intriguing genera within the subtribe Pronophilina. It contains, as currently recognized, two species: A. ica Adams \& Bernard 1977, endemic to the isolated northern Colombian Sierra Nevada de Santa Marta, and A. dryadina (Schaus 1913) confined to the Mesoamerican ranges of Talamanca and Meseta Central in Costa Rica and western Panama. The latter species was described originally in the catch-all genus Catargynnis Röber, 
1892 , later synonymized as a junior synonym of Pseudomaniola Röber, [1889] (Adams 1986).

The available information on Arhuaco is scanty. Adams and Bernard (1977) described the genus for the new species Arhuaco ica Adams \& Bernard, based on male adult morphology, with reference to head parts, wing shape, androconia, color pattern, and male genitalia. Pyrcz (1999) examined the collection of Edwin Krüger and noticed that this German collector found both sexes of $A$. ica some 50 years before Adams and Bernard, but for some reason did not mention it in any of his papers dedicated to Colombian Satyrinae (Krüger 1924, 1925). Pyrcz (op. cit.) also described the female of $A$. ica. Catargynnis dryadina was described by Schaus (1913), and was later listed by Gaede (1931) and illustrated by D'Abrera (1988). The only comment on the behavior and ecology of this species was by De Vries (1987). Pyrcz (2004) transferred C. dryadina to the genus Arhuaco based on similarities in the male adult morphology in comparison with $A$. ica.

Both $A$. ica and $A$. dryadina are considered very rare in the field (Adams \& Bernard 1977, De Vries 1987), which is reflected in the scarcity of available material in scientific collections. Arhuaco ica is known only from a couple of specimens collected by Edwin Krüger in 1919 and 1925, by Michael Adams and George Bernard in 1972 and 1975, and by C. Gibson in 1974 (Adams \& Bernard 1977), and recently from two males collected by Carlos Prieto in 2011 and 2013. The only known female is that collected by Krüger. The meagerness of data on $A$. ica is perhaps not surprising since the Sierra Nevada de Santa Marta, although easily reachable from the coast, has been for many years nearly inaccessible due to political unrest. The scarcity of $A$. dryadina in scientific collections is, however, less understandable. This species occurs in central Costa Rica in the vicinity of large towns, and in areas reachable by asphalt roads. Moreover, the butterfly fauna of Costa Rica is considered as arguably the best investigated among all Central and South American countries (De Vries 1987, 1997, Chacón \& Montero 2007).

To date, only the external morphology of the male of A. dryadina, male and female $A$. ica, and male genitalia of the latter species has been examined. The female of A. dryadina was unknown prior to this study. No molecular data have been published for either species. Thus, opportunities for more rigorous systematic studies have been extremely limited, and the validity of Arhuaco is based exclusively on a comparison of wing shape and color pattern, in particular the configuration of ventral groundplan elements sensu Nijhout (1991). In order to more reliably evaluate the monophyly of Arhuaco, therefore, both male and female genitalia were examined and compared with other genera of Pronophilina, and genetic distances were estimated in order to better establish the systematic position of the two species within the subtribe.
Arhuaco is also particularly intriguing because of its disjunct distribution, which is unique among the cloud forest members of the Neotropical subtribes Pronophilina and Euptychiina. There is no other genus which shows such an atypical pattern, with species found in vastly separated geographical areas. Other satyrine genera occurring in the cloud forests of Central America are either endemic to that region (Drucina Butler 1872, Cyllopsis R. Felder 1869) or widespread throughout the Andes (Oxeoschistus Butler 1867, Pedaliodes Butler 1867, Eretris Thieme 1905, and Lymanopoda Westwood 1851). Conversely, the genera found in the Sierra Nevada de Santa Marta are either endemic (Paramo Adams \& Bernard 1977, Sierrasteroma Adams \& Bernard 1977, the latter, however, synonymized with Steroma Westwood [1850] (Pyrcz 2010)) or widespread (Eretris Thieme 1905, Pedaliodes Butler 1867, Lymanopoda Westwood 1851, and Corades Hewitson 1849). Comparative studies carried out here are therefore expected to shed some light on the possible origins of Arhuaco.

\section{Materials and Methods}

\section{Morphology}

Male and female abdomens of $A$. ica, A. dryadina, and several other species of Pronophilina, as listed in the "Material examined" section, were removed and soaked in $10 \% \mathrm{KOH}$ solution for 5-10 min. Subsequently, the abdomens were preliminarily cleaned of soft tissue in water in order to expose genital parts. Female abdomens were stained in chlorazole black to better visualize weakly sclerotized structures. Dissected genitalia were subsequently cleaned in ethanol $90 \%$ and $95 \%$ solutions. A Nikon digital camera DS-Fi1 and an Olympus SZX9 stereomicroscope were used to take pictures of dissections, and images were then processed in Combine ZP and Corel PHOTO-PAINT $X_{3}$ programs to enhance focus and improve quality. Genital dissections were kept in glycerol vials pinned under corresponding specimens. Genital terminology follows largely Klots (1956). Wing venation pattern and other external macrostructures were examined under a stereomicroscope Delta Optical SZ-630. The following collection acronyms are used: CEP-MZUJ: Nature Education Centre (formerly Zoological Museum) of the Jagiellonian University, Kraków, Poland; MIZPAN: Museum and Institute of Zoology, Polish Academy of Sciences, Warsaw, Poland; NHML: Natural History Museum, London, UK; RCCP: Research Collection of Carlos Prieto, Cali, Colombia; NMNH: National Museum of Natural History, Smithsonian Institution, Washington DC, USA. 


\section{Molecular analysis}

For the DNA analysis, single legs of $A$. ica; $A$. dryadina; Lasiophila regia Staudinger, 1897; Pronophila thelebe Doubleday [1849]; Pronophila unifasciata Lathy, 1906; Pronophila timanthes Salvin, 1871; and Pseudomaniola gerlinda (Thieme, 1907) were removed. Additionally, sequences for six species were imported from GenBank: Lasiophila cirta C. Felder \& R. Felder, 1859; Oxeoschistus leucospilos Studinger, 1876; Oxeoschistus pronax (Hewitson, 1850); Mygona irmina (Doubleday 1849); Junea dorinda (C. Felder \& R. Felder, 1862); and Lymanopoda obsoleta (Westwood 1851) as an outgroup. DNA was isolated using a Sherlock AX (A\&A Biotechnology) extraction kit. Amplification of part of the mitochondrial gene $\mathrm{COI}$ and the nuclear gene $\mathrm{RpS}_{5}$ was done using the following pairs of primers, respectively: LCO1490 and HCO2198 (Folmer et al 1994), HybrpS5degF and HybrpS5degR (Wahlberg and Wheat 2008), with standard PCR protocol. The PCR fragments of $569 \mathrm{bp}(\mathrm{COI})$ and 526 bp (RpS5) were sequenced using a BigDye Terminator v.3.1. Cycle Sequencing Kit (Applied Biosystems, Foster City, CA, USA) and ran on an ABI 3100 Automated Capillary DNA Sequencer. All newly obtained sequences were deposited in GenBank (accession numbers are provided in Table 1). Sequences for each marker were aligned in MAFFT version 7 (Katoh \& Toh 2008) using the default settings, and manually checked against non-conservative alignments in BioEdit 5.0.0. (Hall 1999). Uncorrected pairwise distances were calculated in MEGA version 7 (Kumar et al 2016). A maximum likelihood (ML) topology for $\mathrm{COI}, \mathrm{RpS5}$, and concatenated sequences was constructed using RAxML v8.0.19 (Stamatakis 2014). The strength of support for internal nodes of the ML tree was measured using 1000 rapid bootstrap replicates. All trees were visualized in FigTree v. 1.4.3 (http://tree.bio.ed.ac.uk/software/figtree).

\section{Material examined}

Arhuaco dryadina: Holotype $\left({ }^{\Uparrow}\right)$ : Turrialba, $8200 \mathrm{ft} .$, Aug., Type no. 16781, U.S.N.M, NMNH; $6 \hat{\sigma}$ and 4 O : Costa Rica, Cordillera de Talamanca, Cerro de la Muerte, 2950-3000 m, 01-03.VII.2015, 9³2'30"N, 8343'14"W, T. Pyrcz leg. (DNA extraction numbers $A Z-105, A Z-106 ; 1$ t: prep. genit. 149/ 30.09.2015 J. Lorenc-Brudecka, CEP-MZUJ; 1 q: prep. genit. 41/15.07.2015 J. Lorenc-Brudecka); Arhuaco ica: Holotype $(\widehat{)})$ : Colombia, Sierra Nevada de Santa Marta, East of San Pedro, 2700 m, 06.VIII.1972, M. Adams leg., NHML; 1 đ: Sierra Nevada de Santa Marta, San Pedro, 2400 m, 14.I.2013, $10^{\circ} 53^{\prime} \mathrm{N}, 73^{\circ} 58^{\prime} \mathrm{W}$, i813, C. Prieto leg., RCCP, DNA extract number AZ-212; 1 đ: Sierra Nevada de Santa Marta, San Pedro, $2400 \mathrm{~m}, 11 . \mathrm{l} .2011,10^{\circ} 53^{\prime} \mathrm{N}, 73^{\circ} 58^{\prime} \mathrm{W}, \mathrm{i} 748, \mathrm{C}$. Prieto leg., RCCP; $1 \delta^{\Uparrow}$ : Sierra Nevada de Santa Marta (no exact locality), 2400 m, 27.IX.1919, E. Krüger leg., prep. genit. 150/30.09.2015 J. Lorenc-Brudecka, MIZPAN; 1 q: Sierra Nevada de Santa Marta (no exact locality), 2400 m, 24.VII.1925, E. Krüger leg., prep. genit. 148/29.09.2015 J. Lorenc-Brudecka), MIZPAN; Pronophila timanthes: 1 Costa Rica, Cerro de la Muerte, División - Santa Eduviges, 1900-2050 m, 19.III.2016, 9²9'41"N, 8344'04"W, T. Pyrcz leg., prep. genit. 489/22.11.2016 J. Lorenc-Brudecka, CEPMZUJ; 1 đ̊: Costa Rica, Cerro de la Muerte, División - Santa Eduviges, 1700-1850 m, 04.III.2016, T. Pyrcz leg., MZUJ, prep. genit. 518/15.03.2017 J. Lorenc-Brudecka; 1 đa: Costa Rica, Cerro de la Muerte, División - Santa Eduviges, 17001850 m, 09.III.2016, T. Pyrcz leg., DNA extraction number AZ-249, CEP-MZUJ; 1 đ̊: Costa Rica, Cerro de la Muerte, División - Santa Eduviges, 1900-2050 m, 14.III.2016, T. Pyrcz leg., CEP-MZUJ, DNA extraction number AZ-248; Pronophila rosenbergi puyango Pyrcz, 2000: 1 : Peru, Amazonas, Cocabamba, 2000 m, II.2002, B. Calderón leg., prep. genit. 03/14.04.2016 K. Florczyk, CEP-MZUJ;

Table 1 Genetic pairwise distances between analyzed $\mathrm{CO}$ sequences.

\begin{tabular}{|c|c|c|c|c|c|c|c|c|c|c|c|c|}
\hline Junea dorinda_KU359876 & 0.111 & & & & & & & & & & & \\
\hline Lasiophila cirta_DQ338851 & 0.097 & 0.104 & & & & & & & & & & \\
\hline Oxeoschistus leucospilos_DQ338854 & 0.104 & 0.114 & 0.091 & & & & & & & & & \\
\hline Oxeoschistus pronax_GQ357235 & 0.121 & 0.125 & 0.109 & 0.074 & & & & & & & & \\
\hline Lymanopoda obsoleta_KU359892 & 0.135 & 0.114 & 0.114 & 0.130 & 0.141 & & & & & & & \\
\hline Pronophila thelebe & 0.086 & 0.093 & 0.088 & 0.112 & 0.123 & 0.105 & & & & & & \\
\hline Pronophila unifasciata & 0.091 & 0.093 & 0.091 & 0.112 & 0.120 & 0.104 & 0.053 & & & & & \\
\hline Pronophila timanthes & 0.109 & 0.097 & 0.098 & 0.121 & 0.134 & 0.105 & 0.067 & 0.039 & & & & \\
\hline Arhuaco dryadina & 0.112 & 0.104 & 0.111 & 0.132 & 0.132 & 0.118 & 0.065 & 0.067 & 0.076 & & & \\
\hline Pseudomaniola gerlinda & 0.120 & 0.139 & 0.100 & 0.120 & 0.123 & 0.125 & 0.116 & 0.102 & 0.112 & 0.114 & & \\
\hline Lasiophila regia & 0.091 & 0.100 & 0.056 & 0.091 & 0.105 & 0.102 & 0.086 & 0.083 & 0.093 & 0.107 & 0.095 & \\
\hline Arhuaco ica & 0.086 & 0.084 & 0.077 & 0.105 & 0.120 & 0.105 & 0.065 & 0.033 & 0.054 & 0.076 & 0.107 & 0.069 \\
\hline
\end{tabular}


Pronophila obscura Butler, 1868: 1 : Venezuela, Carabobo, Cerro San Isidro, 1500-1600 m, 10.VIII.2003, T. Pyrcz leg., prep. genit. 04/14.04.2016 K. Florczyk, CEP-MZUJ; Pseudomaniola phaselis argyritis (Thieme, 1907): 1 స: Bolivia, Cochabamba, Villa Tunari - Locotal, 1480-1500 m, 16.II.2009, T. Pyrcz \& Y. Gareca leg., CEP-MZUJ, prep. genit. 97/14.10.2016 A. Zubek; Junea doraete (Hewitson, [1858]): 1 q: Ecuador, Cord. Lagunillas, Jimbura - Laguna Negra, 15.V.1998, A. Jasiński leg., prep. genit. 490/22.11.2016 J. Lorenc-Brudecka, CEP-MZUJ; Lasiophila cirta atropulla Pyrcz 2004: 1 9: Peru, Amazonas, Abra Pardo Miguel, 2200-2400, II.2003, prep. genit. 01/30.03.2016 K. Florczyk, CEP-MZUJ; Mygona irmina (E. Doubleday [1849]: 1 : Venezuela, Aragua, Colonia Tovar, Los Colonos, $2100 \mathrm{~m}$, 25.II.2007, T. Pyrcz leg., prep. genit. 492/22.11.2016 J. Lorenc-Brudecka, CEP-MZUJ; Apexacuta astoreth (Thieme, 1907): 1 q: Peru, Apurimac, Distrito Abancay, Ampay, 3200 m, III.2005, J. Bottger leg., prep. genit. 491/22.11.2016 J. Lorenc-Brudecka, CEP-MZUJ; Cheimas opalinus (Staudinger, 1897): 1 : Venezuela, Trujillo, Guaramacal, Qda. El Caote, 2700-2750 m, 16.Il.2006, T. Pyrcz leg., prep. genit. 488/22.11.2016 J. Lorenc-Brudecka, CEP-MZUJ; Oxeoschistus cothon Salvin, 1871: 1 : Costa Rica, Prov. San Jose, Cerro de la Muerte, Division-Sta Eduviges, 19002050 m, 13.03. 2016, 9²9'41"N, 8344'04"W, T. Pyrcz leg., DNA extraction number AZ-153, prep. genit. 365/11.04.2013 J. Lorenc-Brudecka, CEP-MZUJ.

\section{Results}

\section{Molecular data}

The genetic pairwise distance between analyzed $\mathrm{COI}$ sequences ranged from 3.3 to $13.9 \%$, and from 1.2 to $15.3 \%$ between
RpS5 gene sequences. The genetic distance between Arhuaco and Pronophila was below 7\% (Tables 1, 2). Analysis of $\mathrm{COI}$ resulted in two sister clades, with one grouping three species of Pronophila, A. ica, A. dryadina, and Junea dorinda (Felder \& Felder, 1862), and the second clade consisting of other four genera of Pronophilina (Fig 1). The phylogenetic tree based on RpS5 indicated an internal position of P. gerlinda and A. dryadina within the Pronophila clade, and a sister species position of $A$. ica relative to J. dorinda (Fig 2). The concatenated tree showed the clade comprising Pronophila + Arhuaco, with A. dryadina as sister species to P. thelebe (Fig 3).

\section{Comparative morphology}

The genus Pronophila is morphologically exceptionally homogenous (Fig 4). In addition, its head morphology (hairy eyes, slender antennae approximately two-fifths length of costa gradually widening into a weakly marked club, proportions of the segments of labial palps), venation pattern (long forewing discal veinlet, a well-developed hindwing humeral vein, and cross cu1-cu2 vein bent into discal cell), androconia (very large forewing dorsal androconial patch, covering two thirds of wing surface in median area), male genitalia (stout uncus, long and thin subunci, valva narrowing gradually towards apex with smooth dorsal surface without any dorsal processes and short, straight, tubular aedeagus), and female genitalia (oval bursa with prominent signa, large membraneous pocket enclosing antrum, a single slat-like sclerotized postvaginal process) do not present any consistent differences compared with other genera of the so-called large Pronophilina clade, including Junea Hemming 1964, Eteona Doubleday 1848, Foetterleia Viloria 2004, Daedalma Hewitson 1858, Oxeoschistus Butler 1867, Proboscis Thieme 1907, Lasiophila C. Felder \& R. Felder 1859, Thiemeia

Table 2 Genetic pairwise distances between analyzed $R p S 5$ sequences.

\begin{tabular}{|c|c|c|c|c|c|c|c|c|c|c|c|c|}
\hline \\
\hline \multicolumn{13}{|l|}{$\begin{array}{l}\text { Mygona irmina_GO357610 } \\
\text { Junea dorinda_GO357605 }\end{array}$} \\
\hline Lasiophila cirta_GQ357606 & 0.136 & 0.128 & & & & & & & & & & \\
\hline Oxeoschistus leucospilos_GQ357611 & 0.047 & 0.052 & 0.128 & & & & & & & & & \\
\hline Oxeoschistus pronax_GQ357612 & 0.041 & 0.052 & 0.122 & 0.031 & & & & & & & & \\
\hline Lymanopoda obsoleta_GQ862058 & 0.105 & 0.115 & 0.124 & 0.124 & 0.111 & & & & & & & \\
\hline Pronophila thelebe & 0.043 & 0.019 & 0.126 & 0.049 & 0.045 & 0.111 & & & & & & \\
\hline Pronophila unifasciata & 0.047 & 0.027 & 0.128 & 0.058 & 0.052 & 0.113 & 0.012 & & & & & \\
\hline Pronophila timanthes & 0.047 & 0.027 & 0.128 & 0.054 & 0.045 & 0.115 & 0.012 & 0.014 & & & & \\
\hline Arhuaco dryadina & 0.082 & 0.058 & 0.151 & 0.085 & 0.085 & 0.134 & 0.047 & 0.052 & 0.045 & & & \\
\hline Pseudomaniola gerlinda & 0.072 & 0.052 & 0.153 & 0.078 & 0.070 & 0.140 & 0.037 & 0.039 & 0.025 & 0.070 & & \\
\hline Lasiophila regia & 0.045 & 0.052 & 0.136 & 0.052 & 0.054 & 0.122 & 0.047 & 0.056 & 0.047 & 0.076 & 0.072 & \\
\hline Arhuaco ica & 0.058 & 0.027 & 0.134 & 0.068 & 0.064 & 0.120 & 0.029 & 0.029 & 0.033 & 0.064 & 0.058 & 0.066 \\
\hline
\end{tabular}


Fig 1 RAxML phylogenetic tree based on the COI gene. Bootstrap values are indicated at the nodes.

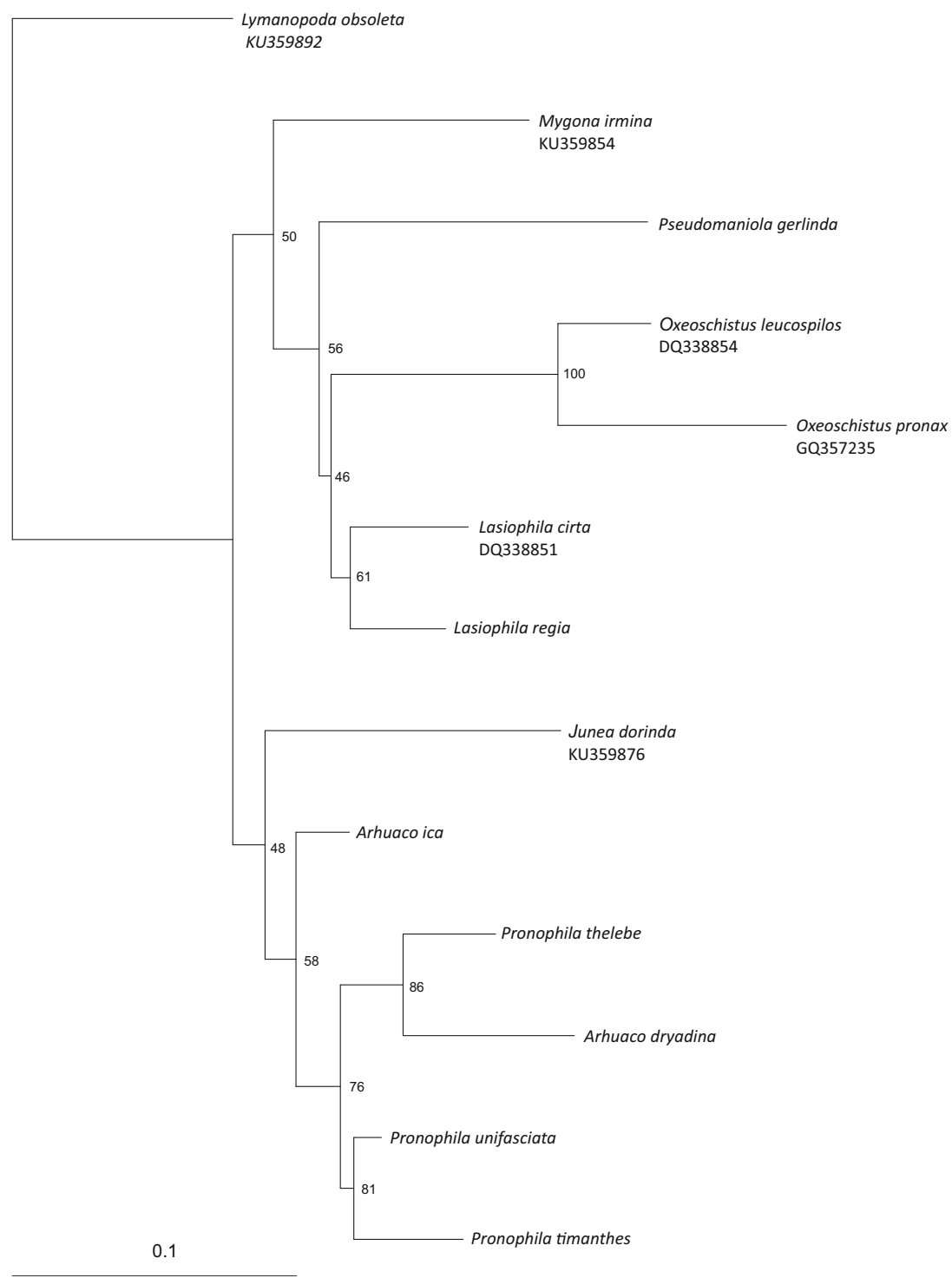

Weymer 1911, Apexacuta Pyrcz 2004, Corades Doubleday [1849] and Pseudomaniola Röber 1889 (excluding some species of the latter two genera whose monophyly is not yet resolved) (Peña et al 2006, Pyrcz 2010), and also Arhuaco.

At the same time, the species of Pronophila are immediately recognized from other genera of this group, including Arhuaco, by a series of characters of wing shape, namely, forewing with a blunt apex and gently concave outer margins; rounded hindwing wider than forewing with wavy outer margins; between three and five large, black forewing ventral submarginal ocelli (in species with white subapical patches the subapical ocelli are subdued) invariably with violet or blue pupils, aligned in a row either parallel to the outer margin or slightly arched basally; and hindwing venter median band darker than the rest of wing's surface, continuous, with a nearly straight basal edge and a distal edge sharply produced distally along discal cell edge.
In Arhuaco (Fig 5), in contrast to Pronophila, the forewing has an acute apex and straight outer margin, the hindwing is subtriangular with a scalloped outer margin with sharp tips at vein ends (in this respect, the wing shape of Arhuaco strongly resembles that of Pseudomaniola, as a result of which A. dryadina has been previously associated with this genus). Importantly, on the hindwing venter, the median band is discontinuous in the discal cell along cross vein $\mathrm{Cu}_{A} 1-\mathrm{Cu}_{A} 2$, with its basal edge connected to the postbasal line (Fig 6). Additionally, on the forewing underside, there is a row of black submarginal ocelli roughly parallel to the outer margin (in $A$. ica, the ocelli do have small violet pupils as in Pronophila, whereas in A. dryadina the pupils are white and very large; in $A$. ica, there are five well-developed ocelli and two in the apex transformed into whitish patches; in A. dryadina, there are as many as eight developed ocelli, including in the apical area in cells R3-R4 and R4-R5, which 
Fig 2 RAxML phylogenetic tree based on the RpS5 gene.

Bootstrap values are indicated at the nodes.

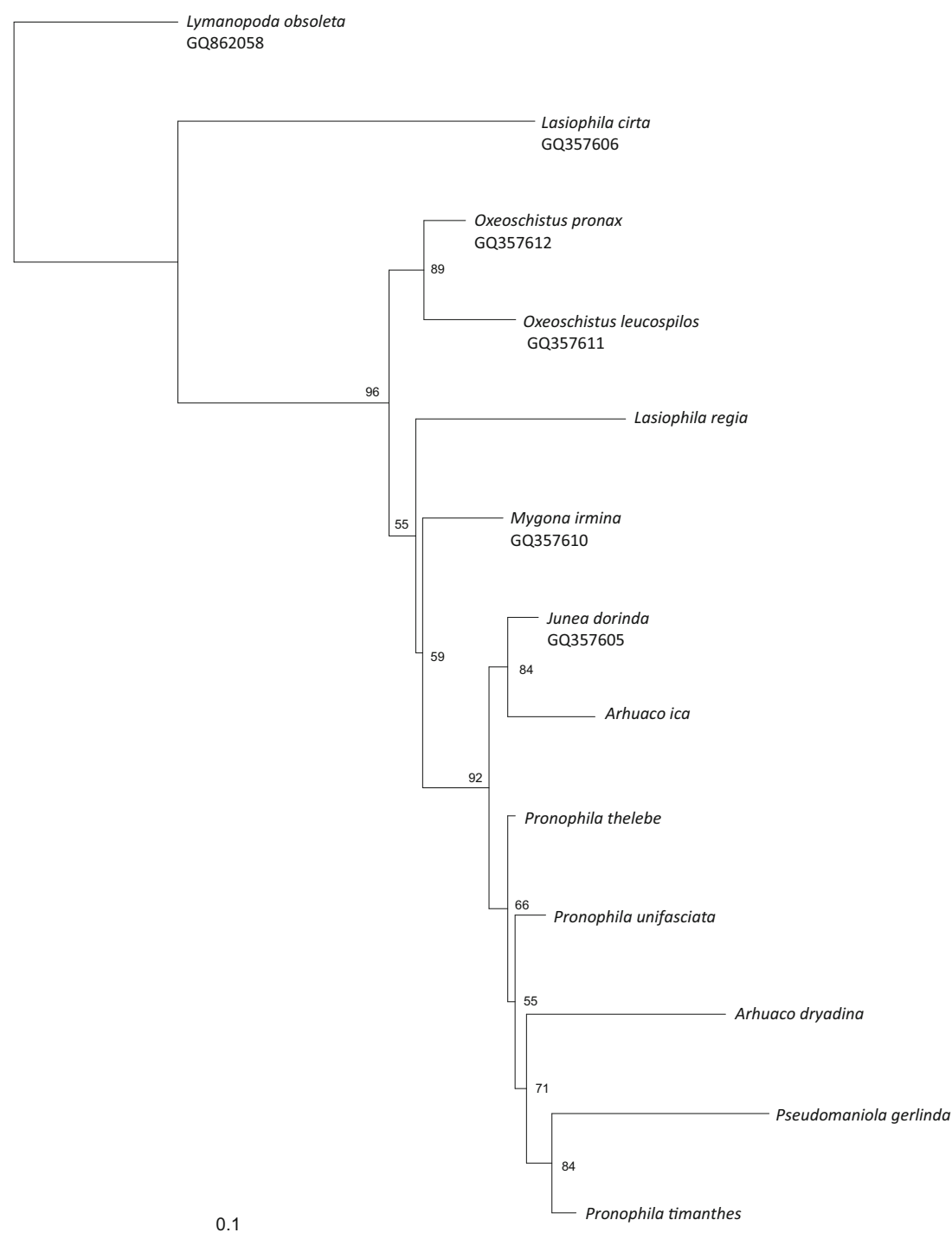

0.1

the upperside, its brown ground color is a shade lighter, and the white submarginal ocellar elements on the fore and hindwing are larger, bordered with a light brown halo, and on the hindwing additionally ringed with red. The underside ground color is lighter, predominantly sandy yellow, except for the basal half on the forewing which is brown with a light yellowish suffusion. The female genitalia (Fig 8) are characterized by an oval bursa with prominent signa, a large membranous pocket enclosing the antrum, and a single slat-like sclerotized postvaginal process.

\section{Diagnosis of Arhuaco}

The original generic diagnosis of Arhuaco (Adams \& Bernard 1977) does not stand in the light of the above comparative study. Consequently, a new diagnosis of the genus Arhuaco is presented as follows: 
Fig 3 RAxML phylogenetic tree based on the joined $\mathrm{COI}$ and $\mathrm{RpS}_{5}$ genes. Bootstrap values are indicated at the nodes.

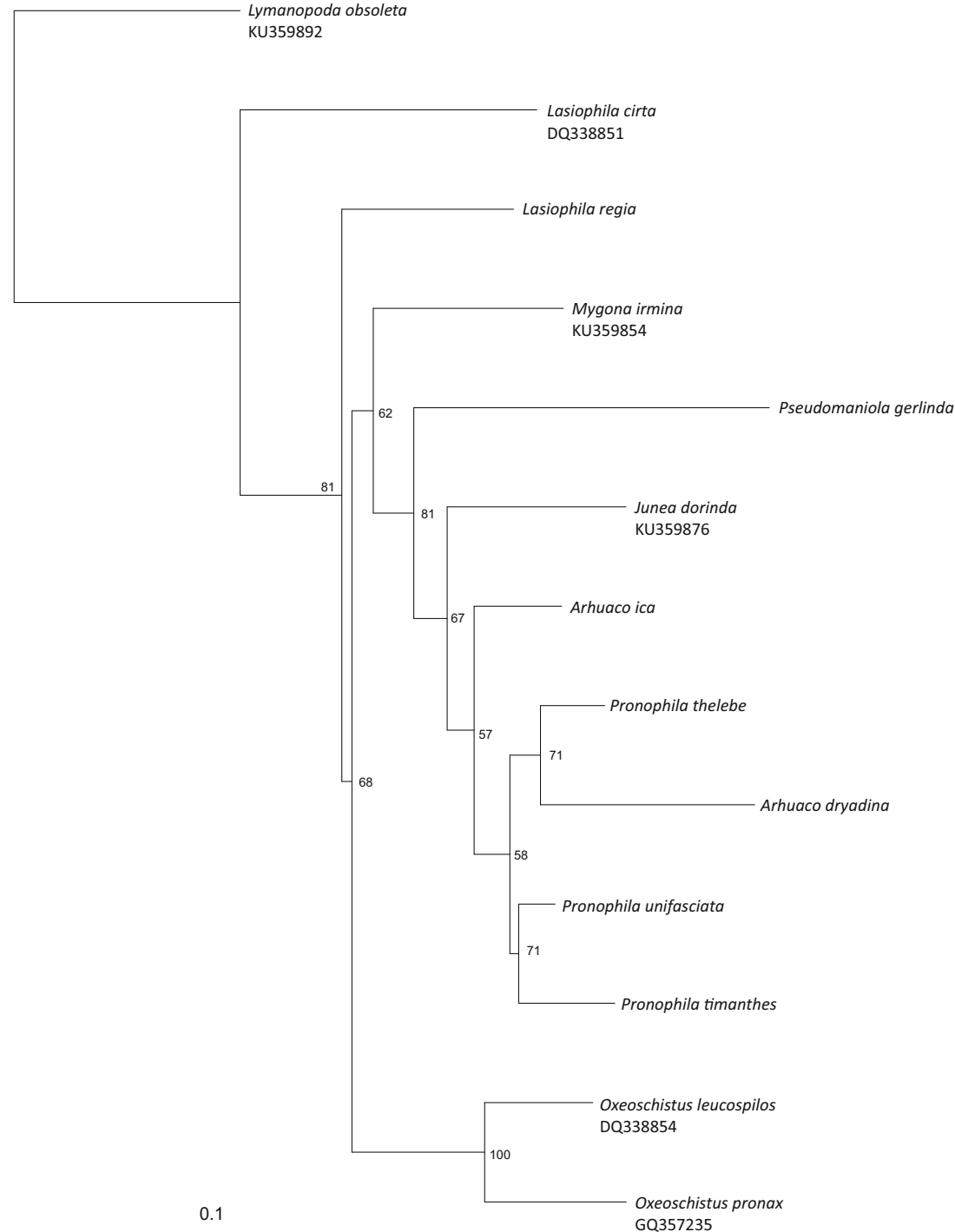

Adults: Forewing with an acute apex (blunt in Pronophila and Mygona) and straight outer margin (produced below apex in Pseudomaniola and Junea); hindwing subtriangular with a scalloped outer margin with sharp tips at vein ends (similar to Junea); hindwing venter postdiscal band discontinuous in discal cell along cross vein $\mathrm{Cu}_{A} 1-\mathrm{Cu}_{A} 2$, with basal edge connected to postbasal line (unlike any other genus of Pronophilina); forewing underside with a row of five to eight black submarginal ocelli roughly parallel to the outer margin (similar to Pronophila), including two, apical in R3-R4 and R4-R5 (unlike any other genus of Pronophilina), transformed into whitish patches in A. dryadina; black hindwing ocelli ringed with red visible on wing dorsal surface (unlike any other genus of Pronophilina). Sexual dimorphism slight, females larger, with lighter hindwing ventral patterns and hindwing ocelli more prominently marked on dorsal surface.
Bionomics

During this research, $A$. dryadina was found in a rather flattened part of the uppermost area of a mountain ridge, with high and predominantly uniform forest cover dominated by oaks (Quercus costarricensis) at 3000-3100 m a.s.l. Individuals are very actively patrolling. Both males and females fly rather rapidly, but not as fast as some other Andean satyrines, such as Corades. On the wing, they resemble somewhat some species of Pronophila or Pseudomaniola, with the difference that they move invariably high above the ground, usually in the canopy, compared to other Andean or Mesoamerican satyrines which can be observed in the subcanopy but frequently descend to ground level. Perching coupled with territorial behavior among the Pronophilina satyrines is typical of very fast flying species in Corades and 


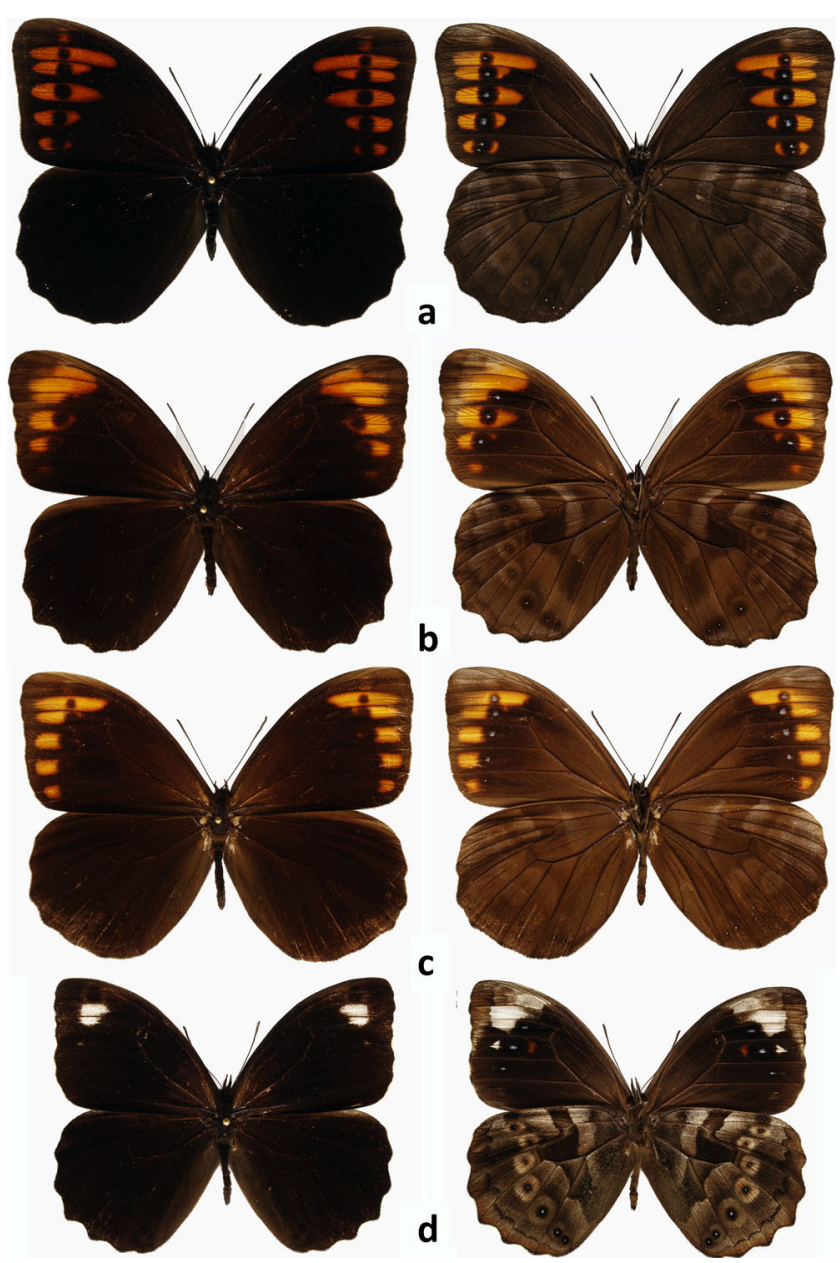

Fig 4 Pronophila adults, males (recto, verso): a Pronophila timanthes, b Pronophila unifasciata unifasciata, c Pronophila thelebina thelebina, d Pronophila thelebe.

Junea, but is also present in some Steremnia Thieme, Daedalma, and Thiemeia. Other genera are either patrolling, or they present intermittent patrolling and perching behavior with no strong territoriality. Individuals, mostly males, observed in Cerro de la Muerte were very active, starting from 8 A.M. when the day was bright from the early morning. When days were mostly cloudy, they started being active during short sunny intervals almost immediately. For most of the time, they were the only active butterflies in the forest, as other species were apparently awaiting an increase in temperature, requiring at least $10 \mathrm{~min}$ of direct sunshine before taking flight. Males displayed patrolling behavior. They flew vigorously, high above the trees, occasionally fluttering and approaching some leaves or flowers, although never settling. They showed an obvious preference for Quercus trees, and, rather surprisingly, they rarely approached the abundant and frequently tall bamboo clumps, contrary to what can be observed with most of
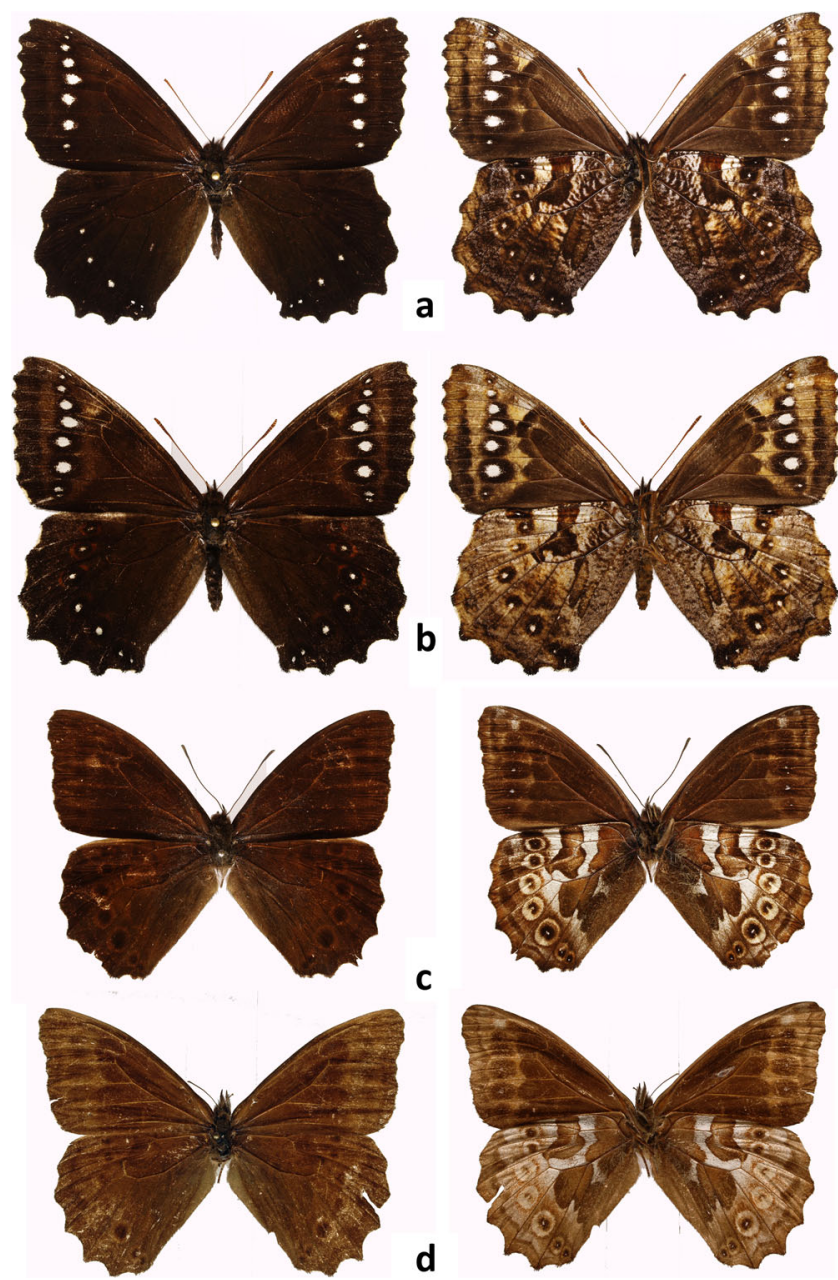

Fig 5 Arhuaco adults (recto, verso): a Arhuaco dryadina male, b Arhuaco dryadina female, c Arhuaco ica male, d Arhuaco ica female.

Andean satyrines, which are most frequently associated with their host plants. They were not attracted to traps placed at 1-2 $\mathrm{m}$ baited with dog excrement, which otherwise proved effective with other local satyrines. They were never observed on hilltops or other prominent topographical features, such as outstanding trees, contrary to territorial Corades and Junea, or non-territorial Steremnia, Pedaliodes or several other genera in the Andes. Male individuals were seen engaging in short interactions consisting of following one another for a short while, probably identifying whether the followed individual was a female, but no contest behavior was observed. No courtship or mating was observed. Individuals of $A$. dryadina spent most of the time in the canopy and were extremely reluctant to approach ground level, which was observed only above a boggy clearing covered partially with Vaccinium and Hypericum bushes. Even then, individuals overflew the plants but never approached within $2 \mathrm{~m}$ of the ground. DeVries (1987) reports $A$. dryadina as a rare butterfly. 

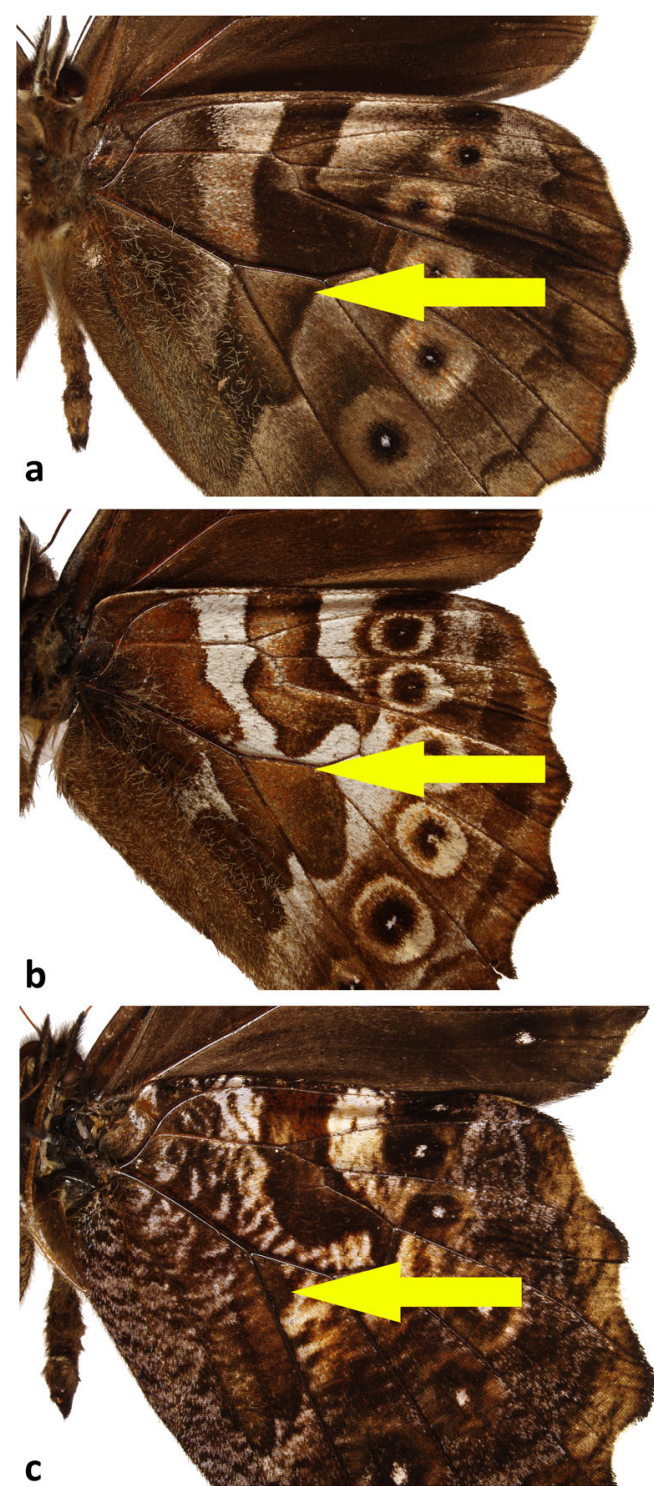

Fig 6 Hindwing ventral color patterns (arrows indicating the distortion of the Nymphalid ground-plan in Arhuaco consisting in the breaking and basal displacement of the postdiscal line-the so-called Pierellization): a Pronophila colocasia, b Arhuaco ica, c Arhuaco dryadina.

This is certainly not the case in the Cerro de la Muerte, where by the end of June and beginning of July A. dryadina was arguably common, and also the most obvious butterfly considering it was very active, patrolling, and a large butterfly that could unlikely be confused with any other species. In February-March (dry season), only one individual of $A$. dryadina was observed in the same area where they were common in June-July (rainy season), which indicates that the species is possibly strongly seasonal. Such important seasonal fluctuation in abundance is uncommon among tropical Pronophilina and has been reported so far only for species occurring in páramo grassland, for example, Steromapedaliodes (Pyrcz et al 2017). The early stages and host plants are not known.
The only information on the ecological preferences of A. ica was published by Adams \& Bernard (1977). They stated that the species is local and mostly rare, and that it has a preference for forest canopy, and rarely descends to the ground. One of the co-authors, however, observed and collected males mud-puddling on the shores of a mountain stream, which shows that occasionally they descend to ground level. Arhuaco ica has been collected so far at 2400-3100 $\mathrm{m}$ a.s.l., therefore in upper elevation cloud forests. The early stages of $A$. ica are not known, but its host plants are almost certainly among Chusquea bamboos, as for other species of high elevation Pronophilina in the Sierra Nevada de Santa Marta.

\section{Discussion}

The currently available morphological and genetic data resulted in incongruent inferences about the relationships among the studied species. In addition, the two sequenced genes $\mathrm{COI}$ and $\mathrm{RpS} 5$ also yielded different results, segregating either the two species of Arhuaco within the Pronophila clade, placing Arhuaco ica as sister to Pronophila + Arhuaco dryadina or indicating $A$. ica as sister to J. dorinda, and even placing Pseudomaniola gerlinda within the Pronophila clade. Although only two genetic markers were studied here, the phylogenies within this section of Pronophilina seem unresolved, and the monophyly of Arhuaco should be considered as uncertain. Interestingly, however, the molecular results strongly indicate a clade composed of Pronophila, Arhuaco, Junea, and Pseudomaniola, and, if adopting a broader taxonomic approach, all these could be lumped within a larger genus Pronophila. These results, incidentally, agree with morphological evidence which indicates close relationships among these genera, possibly forming a monophyletic group.

Putative synapomorphies, especially in the wing shape and color pattern involving the so-called elements of the nymphalid groundplan sensu Schwanwitsch (Nijhout 1991), suggest a closer relationship of $A$. ica with $A$. dryadina than with any other genus or species of the subtribe Pronophilina and indicate that Arhuaco is indeed monophyletic. The broken median band with the basal edge connected to the postbasal line is a rare distortion of the nymphalid groundplan termed "Pierellization" by Schwantwitsch, described for the Haeterini genus Pierella (Nijhout op. cit.). Such a Pierellization in the two species of Arhuaco is a unique state in any genus or species of Pronophilina and was considered to be a strong generic synapomorphy (Pyrcz 2004). On the other hand, the two species do not present any apparent putative synapomorphic characters enabling to associate them with the genus Pronophila, presenting rather some features of other genera, in particular of Junea and Pseudomaniola. 


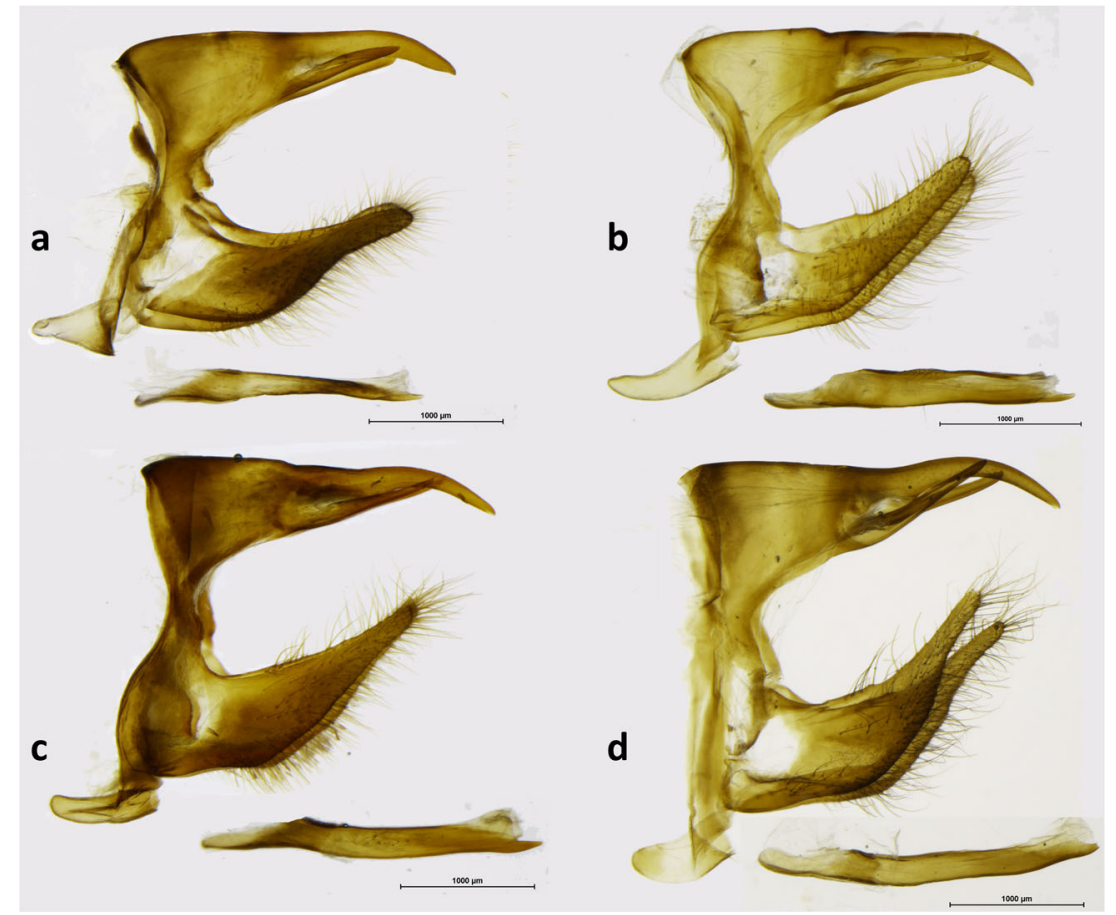

Fig 7 Male genitalia (lateral view, aedeagus extracted): a Arhuaco dryadina, b Arhuaco ica, c Pronophila orcus, d Pronophila timanthes.

Ecological and behavioral data also indicate closer affinities between $A$. ica and $A$. dryadina than with any species of Pronophila. They both occur in the same kind of habitat, high elevation forests, at higher elevations than Pronophila, usually close to the upper forest limit. They also both have an unusual predilection among the Pronophilina for flying in the high canopy and not necessarily in association with bamboo thickets, in contrast to Pronophila which are invariably found in the vicinity of bamboo and generally in the forest understory.

At this stage, there is not enough evidence to ascertain the monophyly of Arhuaco, since it is not supported by molecular data. It would be, however, premature to synonymize Arhuaco with Pronophila given sharp-cut morphological

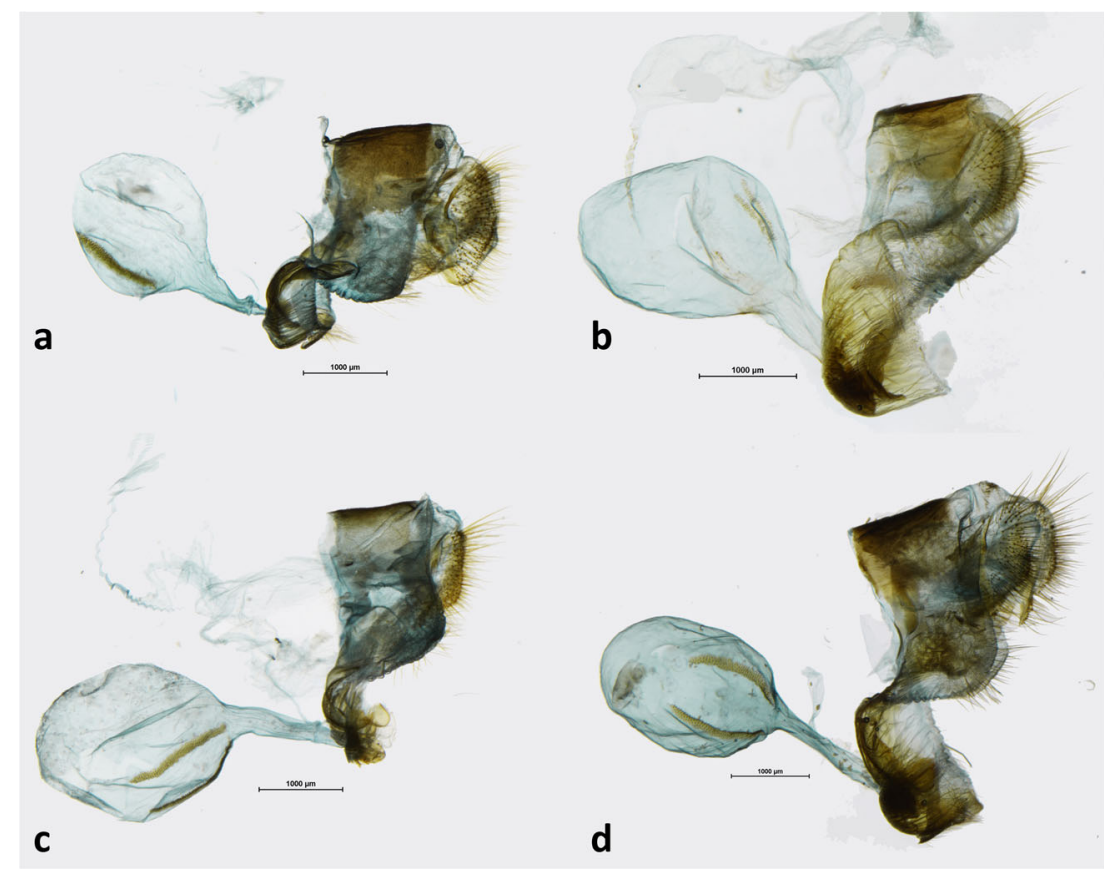

Fig 8 Female genitalia (lateral view): a Arhuaco dryadina, b Arhuaco ica, c Pronophila rosenbergi, d Pronophila timanthes. 
differences between the two. More data are needed, in particular the use of more genetic markers, and the inclusion of even more species of Pronophila as well as other species of Junea and Pseudomaniola in the analysis. It is possible that early-stage data would shed some light on the affinities of Arhuaco and Pronophila, as they have on the status of the genus Daedalma, which has very particular larvae compared to other related genera (Pyrcz et al 2011), but given the scarcity of Arhuaco ica in the field, and the difficulties in finding pronophiline larvae, and rearing them, requiring in situ work, it will be a very difficult task.

The disjunct distribution of Arhuaco in Costa Rica-Panama and northern Colombia, if the genus is confirmed as monophyletic, would be challenging to explain from a biogeographical and evolutionary perspective. Recent, longdistance dispersal of such highly sedentary and habitatspecific montane satyrines between these areas that are currently separated by the vast Colombian plains seems extremely unlikely (Adams 1986, Pyrcz \& Garlacz 2012). Therefore, a vicariance scenario has to be considered. In this case, Arhuaco would originally have had a wider distribution, but disappeared from intervening areas in the northern Andes of Colombia. Such a vicariance scenario would imply that Arhuaco is an old genus within the subtribe which perhaps emerged prior to the radiation of the genus Pronophila. This hypothesis, in turn, could explain, to some extent, the closer genetic relationships with the latter genus and the position of Arhuaco within the larger Pronophila clade.

However, we have to consider that the origins of Arhuaco and, in fact, of other montane species of butterflies belonging to predominantly Andean clades in Central America are presumably linked with the formation of the Isthmus of Panama, and the process of the Great Interamerican Biotic Interchange (GABI). It is generally considered that the land bridge connection between South and Central America occurred only some 3 MYA, and before that higher mountainous areas in Central America were isolated volcanic islands, although some data indicate that such a connection could have existed some 10-15 MYA (Montes et al 2015). The formation of a land connection between these two areas was a precondition of colonization, but, additionally, ecological conditions must have evolved to allow montane species from South America to establish themselves in Central American highlands. This, in turn, could have happened with the cooling of global climate during the Pleistocene and the evolution of ecological corridors of suitable vegetation, hence permitting dispersal from the Andes to the Cordillera de Talamanca. In any case, the timing of such a scenario does not predate the Pleistocene, which is some 1.85 MYA. It is congruent with the distribution of most Central American species of Pronophilina, an overwhelming majority of which are closely related to north Andean taxa, including Lymanopoda euopis Godman \& Salvin, Pedaliodes ereiba Godman \& Salvin,
Pedaliodes lithochalcis Butler \& Druce, Eretris suzannae DeVries, or Pronophila timanthes Salvin (Casner \& Pyrcz 2010, Pyrcz \& Viloria 2012). These are mostly mid- to lowaltitude species whose ancestors presumably dispersed relatively recently from the Andes. However, the presence of the high elevation specialist $A$. dryadina, and indeed of the endemic Mesoamerican genus Drucina represented by one Costa Rican species D. leonata Butler 1872, and by D. championi (Godman \& Salvin, [1881]) from Guatemala and southern Mexico, is difficult to explain by geological and paleoclimatic data on the one hand, and species phylogenetic affinities and the inferred timing of divergence on the other.

Acknowledgments Research permits of TP in Costa Rica were issued by the resolution ACOPAC-IV-001-16 (Evaluación de las estructuras genitales de las mariposas hembras en la resolución de problemas filogenéticos y alfa-taxonómicos de las subtribus Euptychiina y Pronophilina en la Reserva Forestal Los Santos, Pacífico Central de Costa Rica). We would like to thank Marianne Espeland (Forschungs Museum Koenig, Munich) for attempting to obtain additional DNA sequences of Arhuaco ica.

Author Contribution Statement TP designed experimental work and conducted data analysis; JL-B and KF carried out morphological analysis, edited the text and prepared the figures; $\mathrm{ZZ}, \mathrm{BW}$, and DL-C executed molecular analysis and interpreter its results; and TP, CP, and PB carried out field work. TP, PB, CP, and DL-C wrote the manuscript.

Funding Information Research was partially financed from funding from the National Science Center, granted on the basis of decision number DEC-2013/ogNNZ8/03219 and by the Jagiellonian University (K/ZDS/007357).

Open Access This article is distributed under the terms of the Creative Commons Attribution 4.0 International License (http://creativecommons.org/licenses/by/4.0/), which permits unrestricted use, distribution, and reproduction in any medium, provided you give appropriate credit to the original author(s) and the source, provide a link to the Creative Commons license, and indicate if changes were made.

\section{References}

Adams MJ (1986) Pronophiline butterflies (Satyridae) of the three Andean Cordilleras of Colombia. Zool J Linnaean Soc 87:235-320

Adams MJ, Bernard GI (1977) Pronophiline butterflies (Satyridae) of the Sierra Nevada de Santa Marta, Colombia. Syst Entomol 2(4):263-281

Butler AG (1867) Revision of the group of lepidopterous insects hitherto included in the genus Pronophila of Westwood. Ann Mag Nat Hist (3) 20(118):266-268

Butler AG (1872) Descriptions of new butterflies from Costa Rica. Cistula Entomologica 1(4):72-90

Casner KL, Pyrcz TW (2010) Patterns and timing of diversification in a tropical montane butterfly genus Lymanopoda (Nymphalidae, Satyrinae). Ecography 33:251-259

Chacón I, Montero J (2007) Mariposas de Costa Rica. INBIO, San José, p 366 
D'Abrera B (1988) Butterflies of the Neotropical region. Part V. Nymphalidae (Conc.) \& Satyridae. Victoria, Black Rock, Hill House, pp 680-887

DeVries PJ (1987) The butterflies of Costa Rica and their natural history, vol 1, Papilionidae, Pieridae, Nymphalidae New Jersey, Princeton University Press, pp. 456

DeVries PJ (1997) The butterflies of Costa Rica and their natural history, vol 2, Riodinidae Princeton, Princeton University Press, pp. 288

Doubleday E (1849) The genera of diurnal Lepidoptera: comprising their generic characters, a notice of their habits and transformations, and a catalogue of the species of each genus. London, Longman, Brown, Green \& Longmans 1:185-192

Folmer O, Black M, Hoeh W, Lutz RA, Vrijenhoek RC (1994) DNA primers for amplification of mitochondrial cytochrome $c$ oxidase subunit I from diverse metazoan invertebrates. Mol Mar Biol Biotechnol 3: 294-299

Gaede M (1931) Familia Satyridae. Lepid Cat 43:1-320 46:321-544, 48: 545-759

Godman FDC, Salvin, OS (1881) Biologia Centrali-Americana. Insecta. Lepidoptera-Rhopalocera. London, Dulau \& Co., Bernard Quartich, 89-208

Hall TA (1999) BioEdit: a user-friendly biological sequence alignment editor and analysis program. Nucleic Acids Symp Ser 41:95-98

Hewitson WC (1849) Description of a new genus and species of Satyridae. Proc R Soc Lond 16:115-117

Katoh K, Toh H (2008) Recent developments in the MAFFT multiple sequence alignment program. Brief Bioinform 9:286-298

Klots AB (1956) Lepidoptera. In: Tuxen SL (ed) Taxonomists' glossary of genitalia in insect. Munksgaard, Copenhagen, pp 97-110

Krüger E (1924) Beiträge zur Kenntnis der columbischen Satyriden. Entomologische Rundschau 41(2):7) (3):9-10, 16, 19-20, 23-24, 27$28,31-32,35,38-39$

Krüger E (1925) Beiträge zur Kenntnis der columbischen Satyriden. Entomologische Rundschau 42(3):10-12 14, 17-18, 23-26

Kumar S, Stecher G, Tamura K (2016) MEGA7: Molecular Evolutionary Genetics Analysis version 7.0 for bigger datasets. Mol Biol Evol 33: 1870-1874

Lamas G (2004) Checklist: Part 4A. Hesperioidea - Papilionoidea. In: Heppner JB (ed) Atlas of Neotropical Lepidoptera. Volume 5A. Gainesville, Association, pp 205-224

Marín MA, Cadavid IC, Valdés L, Álvarez CF, Uribe SI, Vila R, Pyrcz TW (2017) DNA barcoding of an assembly of montane Andean butterflies (Satyrinae): geographical scale and identification performance. Neotrop Entomol 46(5):514-523

Montes C, Cardona A, Jaramillo C, Pardo A, Silva JC, Valencia V, Ayala C, Pérez-Angel LC, Rodriguez-Parra LA, Ramirez V, Niño H (2015) Middle Miocene closure of the Central American Seaway 348(6231):226-229

Nijhout HF (1991) The development and evolution of butterfly wing patterns. Smithsonian Institution Press, Washington, D.C., p 291

Peña C, Wahlberg N, Weingartner E, Kodandaramaiah U, Nylin S, Freitas AVL, Brower AVZ (2006) Higher level phylogeny of Satyrinae butterflies (Lepidoptera: Nymphalidae) based on DNA sequence data. Mol Phylogenet Evol 40:29-49

Peña CA, Nylin S, Wahlberg N (2011) The radiation of the Satyrini butterflies (Nymphalidae: Satyrinae): a challenge for phylogenetic methods. Zool J Linnaean Soc 161:64-87
Pyrcz TW (1999) The E. Krüger collection of pronophiline butterflies, part 1: introduction, genera Altopedaliodes to Lymanopoda. Lambillionea 99(2):221-240

Pyrcz TW (2004) Pronophiline butterflies of the highlands of Chachapoyas in northern Peru: faunal survey, diversity and distribution patterns (Lepidoptera, Nymphalidae, Satyrinae). Genus 15(4): 455-622

Pyrcz TW (2010) Wybrane zagadnienia z taksonomii, zoogeografii i ewolucji faun górskich na przykładzie grupy modelowej motyli z plemienia Pronophilini (Nymphalidae). Mantis, Olsztyn. pp. 245

Pyrcz TW, Garlacz R (2012) The presence-absence situation and its impact on the assemblage structure and interspecific relations of Pronophilina butterflies in the Venezuelan Andes (Lepidoptera: Nymphalidae). Neotrop Entomol 41(3):186-195. https://doi.org/10. 1007/s13744-012-0031-2

Pyrcz TW, Viloria AL (2012) Revalidation of Pedaliodes lithochalcis Butler \& Druce, description of a new species from Peru and Bolivia and of a new subspecies of $P$. napaea Bates from Honduras (Lepidoptera: Nymphalidae: Satyrinae). Genus 23(1):133-152

Pyrcz T, Wojtusiak J, Garlacz R (2009) Diversity and distribution patterns of Pronophilina butterflies (Lepidoptera: Nymphalidae: Satyrinae) along an altitudinal transect in North-Western Ecuador. Neotrop Entomol 38(6): 716-726

Pyrcz TW, Greeney H, Willmott K, Wojtusiak J (2011) A taxonomic revision of the genus DaedalmaHewitson with the descriptions of twenty new taxa and the immature stages of two species (Lepidoptera: Nymphalidae: Satyrinae). Zootaxa 2898:1-68

Pyrcz TW, Lorenc-Brudecka J, Zubek A, Boyer P, Gabaldón CM, Mavarez J (2017) Taxonomy, phylogeny and distribution of the genus Steromapedaliodes sensu novo in the Cordillera de Mérida, Venezuela (Lepidoptera, Nymphalidae: Satyrinae: Satyrini). Arthropod System Phylogeny 75:195-243

Röber JKM (1889-1892) II. Theil. Die Familien und Gattungen der Tagfalter systematisch und analitisch bearbeitet. In: Staudinger O, Schatz (eds): Exotische Schmetterlinge. Fürth G. Löwensohn, 2(5): 181-224, (6): [5]+ii+225-284

Schaus W (1913) New species of Rhopalocera from Costa Rica. Proc R Soc Lond 1913(3):339-367

Stamatakis A (2014) RAxML version 8: a tool for phylogenetic analysis and post-analysis of large phylogenies. Bioinformatics 30:1312-1313

Thieme O (1905) Monographie der Gattung Pedaliodes Butl. (Lepidoptera. Rhopalocera. Satyridae). Berliner Entomologische Zeitschrift 50:43-141

Wahlberg N, Wheat CW (2008) Genomic outposts serve the phylogenomic pioneers: designing novel nuclear markers for genomic DNA extractions of Lepidoptera. Syst Biol 57:231-242

Westwood JO (1850) In: Doubleday E (ed) The genera of diurnal Lepidoptera: comprising their generic characters, a notice of their habits and transformations, and a catalogue of the species of each genus. London, Longman, Brown, Green \& Longmans, 2:315-326

Westwood JO (1851) In: Doubleday E (ed) The genera of diurnal Lepidoptera: comprising their generic characters, a notice of their habits and transformations, and a catalogue of the species of each genus. London, Longman, Brown, Green \& Longmans, 2:1-2 